\title{
Fair Value Accounting: A Historical Review Of The Most Controversial Accounting Issue In Decades
}

David J. Emerson, University of Memphis, USA

Khondkar E. Karim, Rochester Institute of Technology, USA

Robert W. Rutledge, Texas State University, USA

\begin{abstract}
Historically, there have been many disputes in the area of corporate financial reporting. However, one of the primary issues of disagreement between practitioners, regulators, and theoreticians is that of valuation of financial statement components. The latest twist in the evolution of valuation is the push for (and against) the use of a fair value approach. The purpose of this paper is to examine the history and evolution of how the most critical elements of an entity's financial statements are valued. We provide a history of valuation of financial statement components, and identify the issues involved. Further, we examine the criticisms of actions taken by the regulatory bodies in their efforts to standardize and advance accounting practices. Particularly, we focus on the evolution of fair value measurements. Arguments both for and against the implementation of fair value accounting are provided.
\end{abstract}

Keywords: Fair value, Financial reporting, Valuation

\section{INTRODUCTION}<smiles>c1ccc(CCc2ccccc2)cc1</smiles>
e are at a time when accountants are making headlines with the push toward fair value financial reporting. The Financial Accounting Standards Board (FASB), and the International Accounting Standards Board (IASB) are moving forward with rules that increase the use of fair value measurements. While most of the constituents are on board the "fair value train," recent developments in the market have some crying foul. For example, bank failures and the sub-prime market meltdown have been attributed to fair value accounting (King, 2009). In a letter to the SEC, the American Bankers Association stated that the crisis in today's financial markets has been exacerbated by the implementation of fair value accounting (American Bankers Association, 2008). Congress even ordered the SEC to study if mark-to-market (a.k.a., fair value) accounting helped to accelerate the meltdown of the US financial system.

How did we get to this point in the evolution of accounting valuation? What caused us to be in a situation where there is so much disagreement and uncertainty? Ever since Pacioli codified double-entry bookkeeping in 1494, accountants and others have been concerned with the issues surrounding the valuation of financial statement components. Pacioli enabled future generations by developing a system for Venetian merchants to track and value their activities in a relatively accurate way. It is the inherent choices that must be made when employing Pacioli's accounting model that reverberate in the current debate.

The investment landscape changed when capital markets were opened to the general populous after World War I. Capital markets flourished in an atmosphere similar to that which Alan Greenspan would later call "irrational exuberance." This was the era of unrestrained exploitation of anything capable of being exploited. Thus, it should not be surprising that manipulation of the capital markets contributed to the infamous 1929 stock market crash. Nor is it surprising that investors and creditors are continually attempting to retain confidence in the capital markets. 


\section{EARLY ACCOUNTING REGULATION}

Following the stock market collapse in 1929, the New York Stock Exchange approached the American Institute of Accountants (AIA) seeking assistance in formulating standards by which exchange-listed companies must comply. The principles adapted from the AIA's recommendations represent the first iteration of what would eventually become known as the Generally Accepted Accounting Principles (GAAP) in the United States.

Another consequence of the stock market failure was the creation of the Securities and Exchange Commission (SEC). Formation of this body in 1934 initiated governmental oversight and control of the capital markets. Although Congress has gave the SEC the responsibility and the authority to regulate any and all aspects of accounting for listed companies, the body generally was reluctant to do so; preferring instead to allow accountants to regulate themselves. Accountants responded to the delegated responsibility of self-governance by forming a committee: The Committee on Accounting Procedure (CAP). For several years after its creation, the CAP did little to solve the problems of financial reporting theory formation and financial statement standardization.

The SEC soon tired of this inaction, and in 1938 issued a pronouncement (Accounting Series Release No. 4), requiring that all official filings must have "substantial authoritative support." This pronouncement spurred the CAP into action. They soon began issuing guidance in the form of Accounting Research Bulletins (ARBs). Because ARBs were issued on a somewhat ad hoc basis, they did little to solve the fundamental issues (e.g. asset valuation strategies) that they were intended to address. In the absence of a comprehensive theory on which to base policy, the volume of accepted practices grew at a significant rate and ultimately provided a number of acceptable means to address most issues. This caused a lack of comparability between firms due to the diversity of possible accounting treatments.

The CAP continued to exist for twenty years until it became apparent that the status quo could no longer be maintained. Thus, in 1959 the American Institute of Certified Public Accountants (AICPA) disbanded the CAP, and replaced it with two separate organizations: the Accounting Principles Board (APB) and the Accounting Research Division (ARD). These organizations were charged with reducing the number of allowed accounting practices under GAAP, codifying GAAP, and providing proactive solutions to emerging issues. The ARB and APD approached their mandate with a two-part strategy. First, they would develop a comprehensive theory of accounting, followed by the adoption of a number of principles based on that theory. This was an excellent plan...in theory.

By 1961 the first phase was complete as evidenced by the issuance of Accounting Research Study (ARS) No. 1, which provided a set of postulates that would form a foundation for subsequent accounting principles. These postulates were relatively uncontroversial and reflected a generic view of the political, economic, and sociological status of accounting. When the ARD released the companion study to the theoretical postulates, however, the reaction was nowhere near as benign.

The release of ARS 3 in 1962 can be viewed as the birth of the modern era of accounting. The principles contained therein do not seem particularly radical today, but the study contained provisions that questioned the primacy of historical cost for asset valuation. Specifically, the study recommended that any changes in the value of assets that could be "objectively determined" should be recognized (Accounting Principles Board, 1962). The types of changes included events such as changes in price levels, changes in replacement costs and changes due to other causes. There was a negative reaction to the ARD's proposal. Even its parent body, the AICPA, responded officially only months after ARS 3 was released. In its response, the governing board stated "that while these studies are a valuable contribution to accounting thinking, they are too radically different from present GAAP for acceptance at this time" (American Institute of Certified Public Accountants, 1962). The nearly unanimous rejection of the proposed principles, combined with political missteps greatly reduced the significance of the APB and ARB.

\section{CONCEPTS OF VALUATION}

Philips (1963) provided a new perspective on valuations. He examined the issue of income determination, and identified five distinct methods by which income may be determined. Presented as a continuum with increasing 
objectivity and reliability, and decreasing conceptual reasonableness (relevance), the concepts listed include (Philips 1963, 14):

1. Psychic income - Purely subjective. Income is what the individual perceives it to be.

2. Economic present value added - Discounted present value of future cash flows.

3. Accretion income - The increase in economic power as measured by changes in the market value of assets. This is fair value accounting, which is also known as value relevance accounting.

4. Accrual income - Transactionally determined income. Recognizes revenues when earned and expenses when incurred in support of revenues. Traditional accounting model.

5. Cash income - Strictly objective. Income determined by cash inflows and outflows.

The next iteration of accounting theory was provided by the American Association of Accountants (AAA).

In 1964, the AAA formed a committee tasked with developing "an integrated statement of basic accounting theory." Released two years later, A Statement of Basic Accounting Theory (ASOBAT) represented a significant departure from traditional accounting thought on several levels (American Accounting Association, 1966), including:

1. emphasizing communication as a primary purpose of financial information,

2. stressing the importance of the users of the financial information, and the ways in which the provided information was used to make decisions,

3. recognizing the importance of accounting and the custodial duties entrusted to accountants due to their role in maintaining records and reporting the results of economic activity, and

4. acknowledging the macroeconomic role that accounting plays in society.

The AAA report recommended that four standards be adopted and adhered to when disseminating accounting information (American Accounting Association, 1966): relevance, verifiability, freedom from bias, and quantifiability.

The highest status was given to relevance because of its inherent connection with the financial statement user. Stressing relevance as the most important characteristic of accounting information clearly emphasizes that the usefulness of accounting information is directly related to its relevance. Verifiability was given a lower status implying that the objective determination of balances is less pertinent to the user than the relevance of those balances.

ASOBAT is extremely pertinent to any discussion of fair value reporting, both through its emphasis on relevance, as well as through the inclusion of a proposal that would allow entities to provide multiple measures of transactional information. This "dual-reporting" proposal was seen as an effort to transition the industry away from historical cost toward the more relevant measure of fair value. Several concerns were raised regarding ASOBAT, including criticisms of the assumption that industry financial statement preparers know and understand what information users need. Once again, the most strident opposition focused on the use of fair value as a method for asset valuation.

The APB was in conflict with the SEC around this same time. This severely weakened the APB's ability to perform its duties. Major concerns about financial reporting in general and a conspicuous lack of a framework on which to base policy contributed to the 1971 creation of two new committees: the Trueblood Committee, and the Wheat Committee. These committees were given the dual task of performing a comprehensive review of accounting policy, and assessing the process under which standards were set.

The Trueblood Committee, chaired by Robert Trueblood, issued a report in 1973 that quantified the objectives to be achieved in financial reporting. Mirroring ASOBAT in many ways, the report emphasized the primacy of providing "information that is useful to users in making economic decisions" (American Institute of Certified Public Accountants, 1973, 281). The report directly addressed the issue of asset valuation, determining that the objectives contained within the report "could not be served by the use of a single valuation basis such as historical cost." 
The Wheat Committee, under the guidance of Frances Wheat, developed the current system of standard setting by recommending that a tripartite structure be created to generate and implement financial standards. The primary agent in this structure is the Financial Accounting Standards Board (FASB) which was created in July 1973, and the APB was disbanded.

The debate over asset valuation continued under the FASB, beginning with the issuance of Statement of Financial Accounting Concept (SFAC) No. 5 in 1984. This statement, entitled "Recognition and Measurement in Financial Statements of Business Enterprises" provided guidance on both recognition criteria, and the manner in which items should be valued. SFAC 5 listed five alternative methods for valuation (FASB, 1984): (1) historical cost, (2) current cost, (3) current market value, (4) net realizable value, and (5) present value.

The FASB expressed no specific preference for any of the available alternatives for valuation in the belief that each method is appropriate depending on the circumstances. Rather than introduce radical changes into the accounting model, the FASB chose to issue the statement while avoiding any immediate implementation of the concepts contained therein.

SFAC 5 was one of a set of statements designed to create the long desired, conceptual foundation on which all future policies could be based. The inclusion of various measures of valuation into this conceptual framework provided the organization with the means and justification for its later actions in this contentious area of financial accounting.

The FASB has returned to the topic of asset valuation many times, specifically in Statements of Financial Accounting Standards (SFAS) numbers 87, 105, 107, 115, 119, 121, 123, 123R, 133, 157, and 159. These statements of financial standards have incrementally and systematically advanced the use of valuation methods that provide a more relevant measure of value than that provided by historical cost. These changes have not occurred in a vacuum, and the organization has been subjected to much criticism as the issues have been debated and implemented.

\section{RATIONALE FOR FAIR VALUE ACCOUNTING}

The crux of what is labeled "fair value accounting" includes: (1) asset and liability recognition, (2) the treatment of income as a residual, and (3) the expectation that balance sheet values sum to the market valuation of the company. It should be noted that historical cost accounting is not the opposite of fair value accounting, but may be more accurately viewed as its evolutionary antecedent.

Jones (1988) analyzes the issues related to historical cost versus fair value in accounting for financial instruments. Jones states that the diversity of financial instruments had grown significantly in previous years, and with that growth came valuation issues. He points out that historical cost no longer, "faithfully represent(s) the economic realities of today's complex instruments" (Jones, 1988, 56). He suggests two fundamental issues are common to many of the divergent financial instrument transactions (Jones, 1988, 58): (1) whether transactions should be treated with sale accounting techniques or if a borrowing treatment is more appropriate when financial assets are converted to cash, and (2) whether certain financial liabilities should be considered settled or extinguished in certain circumstances.

When dealing with financial assets, the current model at the time provided firms the opportunity to structure and account for transactions in a way that earnings could be easily managed, and yet remain in compliance with GAAP. For example, similar transactions could be reported as a borrowing if sale accounting would show a loss, but reported as a sale if it would result in a gain (or if there was already excessive debt reported on the balance sheet). Fair value accounting could eliminate some of the motivations of managers who might take advantage of these inconsistencies.

Several issues are directly associated with fair value reporting, including recognition, relevance and measurement. With regard to recognition, the evolution in capital markets makes it possible for companies to recognize and record economic events (i.e., fair values related to financial instruments) in their financial statements. 
The issue of relevance should be considered within the context of managerial intent. For example, if management holds financial instruments for their yield, then amortized cost is most appropriate. However, if management's intent is to hold financial instruments for potential value increases, then fair value would me most appropriate. Measurability becomes a major issue, particularly when valuing items that are not actively traded or quoted on any exchange. Such valuation could create difficulties with consistency across different classes of assets.

\section{FASB INITIATIVE RELATED TO FAIR VALUE ACCOUNTING}

Many of Jones' (1988) predictions were ultimately realized with the FASB's issuance of SFAS 115, Accounting for Certain Investments in Debt and Equity Securities. Narrowly constructed and defined, the statement provided guidance on the valuation of "investments in equity securities that have readily determinable fair values and for all investments in debt securities" (FASB, 1993). The FASB was cognizant of the relationship between valuation and managerial intent, as evidenced by the statement's requirement that firms declare their intentions with regard to investment instruments. Indeed, this distinction provides the means for differentiation between valuation methods.

As required by SFAS 115, debt securities that are "held to maturity" were to be reported at amortized cost. Debt and equity investments with readily determinable market values that were designated as "trading," were reported at fair value and any unrecognized gains or losses included in income. Those investments that were not assigned to either of the above listed categories were deemed to be "available for sale." Investments of this type were also reported at fair value, but any unrecognized gains or losses were reported as a separate component of shareholder's equity.

Because the FASB was aware of the possibility of earnings management and the manipulation of an investor's perceived magnitude of risk within a firm's portfolio, the statement required a firm to have the ability and positive intent to hold an investment to maturity before it could be so designated. Any transfers between the categories were to be accounted for as sales and repurchases at fair value. The statement also provided specific guidance as to the determination of positive intent.

Reaction to SFAS 115 was mixed. Those that favored historical cost valuation were upset because of the departure from tradition, whereas fair value proponents were disappointed that the statement did not go far enough. In general, however, SFAS 115 was seen for what it was; an official response to a genuine concern about how marketable securities were valued and reported. Some questions were left unaddressed, such as the reporting of some or all liabilities at fair value and off-balance sheet obligations. However, this was the FASB's favored incremental approach to implementing fair value reporting. As suggested by Parks (1993, 52), SFAS 115 was "clearly a compromise and more evolutionary than revolutionary."

During the mid-1990s, the FASB issued several statements relevant to this discussion, including: SFAS 119 (Disclosure about Derivative Financial Instruments and Fair Value of Financial Instruments); 121 (Accounting for the Impairment of Long-Lived Assets and for Long-Lived Assets to Be Disposed Of); and 123 (Accounting for Stock-Based Compensation). SFAS 119 and SFAS 121 have been superceded and SFAS 123 has been substantially amended, as the FASB continued to fine tune its intentions. The relative rapid advancement of fair value methods and the issuance of official guidance, combined with the equally rapid pace of revisions and supercessions, are indicative of the intensity of the debate during this time frame.

Barth and Landsman (1995) contributed to this debate by responding to the FASB's Discussion Memorandums regarding, "The Recognition and Measurement of Financial Instruments," and "Distinguishing between Liability and Equity Instruments," and addressed some of the fundamental issues surrounding the topic of fair value. They, "assume that fair values (are) conceptually relevant to financial statement users in assessing firm value, and define a financial statement item to be value-relevant if the information it reflects helps financial statement users to assess firm value."

The FASB defined a financial instrument's fair value as, "the amount at which the instrument could be exchanged in a current transaction between willing parties, other than in a forced or liquidation sale" (FASB, 1991). 
Barth and Landsman suggest that this definition is too limiting, because fair value is not well defined in imperfect or incomplete markets. They stipulated that there are three primary fair value metrics: (1) entry value - the purchase price, or if price levels change, the asset's replacement cost, (2) exit value - the price for which the asset can be sold, and (3) value-in-use - the incremental value that the asset provides the firm.

According to Barth and Landsman, the FASB's perspective should focus on exit value, because their primary concern is the "financial reporting of a firm's assets in place and not assets to be acquired" (Barth and Lansman, 1995, 103). Thus, their definition of fair value should be interpreted from the seller's perspective (i.e. exit value). Value-in-use is indicative of management skill, and such skill could be quantified as the difference between value-in use and exit value. Because of the subjective nature of value-in-use, such a metric would be difficult to implement due to the necessity of incorporating proprietary information. Due to this difficulty, either exit or entry valuations could be relevant, depending on circumstances.

The possibility for significant error due to uncertainty or material discretion introduces a counter-argument against fair value accounting. Proponents claim that fair value accounting, by definition, reduces managerial ability to manage earnings. However, manipulation of reported values, either intentionally or by using internal information for advantage, can result in the very effect that fair value accounting is designed to eliminate. Managers may be motivated to realize gains or losses on a selective basis in order to manipulate financial statement users' evaluations.

Landsman (2007) addresses the issue of value manipulation, and notes that the requirement of relying on managerial estimates for valuation of assets and liabilities introduces the problem of information asymmetry. Information asymmetry will arise, "whenever managers have discretion regarding the timing or amount of nonmarket adjustments to amounts arising from past transactions" (Landsman, 2007, 26). Such information asymmetry creates two distinct problems; moral hazard and adverse selection.

Moral hazard will occur when managers benefit by using their private information to manipulate the information they disclose. Further, adverse selection implies that the market will view similar instruments that are held by different entities similarly, even though their actual values are significantly different. Although the intense scrutiny that companies are subjected to has the effect of keeping firms and their managers honest; it does so with a noticeable time lag. An effective countermeasure to the estimation measurement problem is a requirement for disclosure of the underlying assumptions used when estimating fair value.

Barth (2006) contributes to the debate in her capacity as a member of the International Accounting Standards Board (IASB). She addresses the question of fair value accounting within the context of the issue of including estimates of future cash flows in an entity's financial statements. While such a discussion is beyond the scope of this paper, some of the points she raised about fair value are especially pertinent. Barth addressed the topic of multiple measures for financial instrument valuation, recognizing that such use is "not only conceptually unappealing, but also creates difficulties for financial statement users" (Barth, 2006, 274).

Using different measures provides the opportunity for similar economic events to be presented in very different ways. Using a single measurement attribute alleviates many of the difficulties associated with the present use of multiple measurement attributes. Barth states the, "Fair value accounting is the only comprehensive and internally consistent approach" (Barth, 2006, 274). The use of fair value measures provides the qualitative characteristics of relevance, comparability, consistency and timeliness that are essential for financial statement reporting.

Fair value is relevant because it accurately reflects current market conditions, which are the same conditions under which most investors will use the information. The use of fair value is comparable because the value of an instrument is dependant on the instrument itself, rather than within the context of the entity that owns it. Fair value is consistent because it reflects the same relative information from period to period. Lastly, fair value is timely because it accurately portrays the effect of economic events on an entity over time.

The FASB added to the fair value discussion in late 2006 and early 2007 with the release of SFASs 157 (Fair Value Measurements) and 159 (The Fair Value Option for Financial Assets and Financial Liabilities). The 
purpose of these standards is to, "increased consistency and comparability in fair value measurements and for expanded disclosures about fair value measurements" (FASB, 2006), and "to improve financial reporting by (reducing) volatility in reported earnings caused by measuring related assets and liabilities differently" (FASB, 2007). Thus, both statements improve consistency and comparability, and increase the use of fair value accounting. Increasing the use of fair value reporting is consistent with the FASB's long-term objectives. With this new guidance, the FASB extended the list of financial statement items that may be valued at fair value to include:

1. Loans receivable and payable

2. Investments in equity securities

3. Rights and obligations under insurance contracts

4. Rights and obligations related to warranty agreements

5. Host financial instruments that are separated from embedded derivative instruments

6. Firm commitments involving financial instruments

7. Written loan commitments

It should be noted that many of the concerns raised by Landsman (2007) regarding disclosure were addressed in the statements so that, "financial statement users will be able to clearly understand the extent to which the (fair value) option is utilized, and how changes in fair values are being reflected in the financial statements" (Ratcliffe, 2007, 59).

\section{RECENT OPPOSITION TO FAIR VALUE ACCOUNTING}

Just as there are many advocates for the adoption of fair value measures, there are many influential voices in opposition. Holthausen and Watts (2001) identify several issues that undermine the arguments supporting fair value. First, they contend that value relevance accounting does not provide the necessary predictive and explanatory powers required of accounting information. Second, they argue that value-relevance measures, "omit some factors that the FASB states are important for assessing whether information is useful and include some factors that are contrary to FASB statements" (Holthausen and Watts, 2001, 13). Lastly, they contend that proponents of fair value assume that equity investors are the primary users of financial reporting, and this is belied by FASB's statements to the contrary. Indeed, the FASB has never claimed that the purpose of accounting is to provide direct estimates of value.

McCarthy (2004) suggests that that the FASB's motivation to advance fair value accounting is based in an inherent bias in favor of international accounting firms. He attributes the FASB's movement toward fair value accounting principles as biased in a desire to be in compliance with international standards, thereby serving the Big Four. He believes that, "the reliability offered by historical financial reporting is infinitely more valuable to the vast majority of financial report users than the collective accumulation of statistical probabilities offered by fair value" (McCarthy, 2004, 18). He suggests that the replacement of historical cost accounting with fair value accounting will cause the concept of objectively to disappear in accounting.

Flegm (2005) argues for historical-cost-based valuations because of the inherent objectivity associated with such measurements. The recent largest frauds in management history were "enabled" by the move towards fair value accounting. For example, many of Enron's valuation overstatements resulted from fair value estimates (Benston, 2006). Flegm reasons that a certain percentage of people are unethical and greedy. They will take advantage of the subjectivity that is afforded by fair value accounting. It is necessary to reduce the subjectivity in accounting in order to avoid this behavior. Historical cost based valuations are objective, have stood the test of time, and provide a solid base for auditors to form an opinion.

\section{CONCLUDING COMMENTS}

The issues surrounding fair value accounting are numerous and many powerful forces are opposed to its implementation. U.S. industry groups are pressuring the SEC and FASB to significantly alter or suspend the accounting rule, saying it is undermining the government's multibillion-dollar effort to stabilize the country's financial sector. Fair value accounting is being blamed for forcing banks to report billions of dollars in write-downs, 
and contributing to the meltdown of the capital markets. A U.S. House Financial Services subcommittee held a hearing on mark-to-market accounting rules and fair value accounting. A result of this subcommittee was the Emergency Economic Stabilization Act of 2009.

Subsequently, the SEC studied relevant accounting standards and recommended that existing fair value requirements need to be modified in order to improve related application and practice. In particular, the SEC stated that guidance was needed for "determining fair value in illiquid or inactive markets." The FASB provided this guidance by issuing four Staff Positions. The latest is Staff Position No. FAS 157-4 (FASB, 2009) which states that the objective of fair value measurement has not changed even though markets have seen significant volume decreases and disruption. Fair value is the price of an asset or liability in an orderly transaction. This is not necessarily the latest transaction price, and not the price in a forced liquidation or distressed sale. The FASB has made the point that the intent of its recent actions is to improve the overall state of financial reporting; not as a response to political pressure, or as a means to achieve a particular accounting result.

There may be valid arguments coming from those opposed to fair value accounting, but the reality is that fair value reporting is here to stay in one form or another, and will be further expanded. The FASB is to moving incrementally toward fair market value, if for no other reason than to enhance comparability with international standards. As the difference between U.S. GAAP and international standards continues to narrow, the use of fair value is likely to continue its expansion.

\section{REFERENCES}

1. Accounting Principles Board. 1962. Accounting Research Study (ARS) No. 3: A Tentative Set of Broad Accounting Principles for Business Enterprises. (Accounting Principles Board).

2. American Accounting Association. 1966. A Statement of Basic Accounting Theory. Evanston, IL, American Accounting Association.

3. American Institute of Certified Public Accountants. 1973. Objectives of Financial Statements. New York, NY, AICPA.

4. American Institute of Certified Public Accountants. 1962. Accounting principles board comments on 'broad principles,' Journal of Accountancy: 113 (5): 9-10.

5. $\quad$ American Bankers Association. 2008. Letter to SEC. September 23, 2008.

6. Barth, M. E. 2006. Including estimates of the future in today's financial statements. Accounting Horizons 20 (3): 271-285.

7. Barth, M. E., and W. Landsman. 1995. Fundamental issues related to using fair value accounting for financial reporting. Accounting Horizons 9 (4): 97-107.

8. Benston, G. J. 2006. Fair-value accounting: A cautionary tale from Enron. Journal of Accounting and Public Policy 25 (4): 465-484.

9. FASB. 2009. Staff Position No. FAS 157-4: Determining Fair Value When the Volume and Level of Activity for the Asset or Liability Have Significantly Decreased and Identifying Transactions That Are Not Orderly (http://www.fasb.org/pdf/fsp fas157-4.pdf).

10. FASB. 2007. Statement of Financial Accounting Standards No. 159: The Fair Value Option for Financial Assets and Financial Liabilities - Including an Amendment of FASB Statement No. 115. Norwalk, CT: Financial Accounting Standards Board.

11. FASB. 2006. Statement of Financial Accounting Standards No. 157: Fair Value Measurements. Norwalk, CT: Financial Accounting Standards Board.

12. FASB. 1993. Statement of Financial Accounting Standards No. 115: Accounting for Certain Debt and Equity Securities. Norwalk, CT: Financial Accounting Standards Board.

13. FASB. 1991. Statement of Financial Accounting Standards No. 107: Disclosures about Fair Value of Financial Instruments. Norwalk, CT: Financial Accounting Standards Board.

14. FASB. 1984. Statement of Financial Accounting Concepts No. 5: Recognition and Measurement in Financial Statements of Business Enterprises. Norwalk, CT: Financial Accounting Standards Board.

15. Flegm, E. H. 2005. On solving the problem, not being it. The CPA Journal 75 (2): 12-14.

16. Holthausen, R. W. and R. L. Watts. 2001. The relevance of the value-relevance literature for financial accounting standard setting. Journal of Accounting and Economics. 31 (1-3): 3-75. 
17. Jones, J. C. 1988. Financial instruments: Historical cost v. fair value. The CPA Journal 58 (8): 56-63.

18. King, A. M. 2009. Determining fair value. Strategic Finance 90 (7): 27-32.

19. Landsman, W. R. 2007. Is fair value accounting information relevant and reliable? Evidence from capital market research. Accounting and Business Research 37 (3): 19-30.

20. McCarthy, P. D. 2004. Unnecessary complexity in accounting principles. The CPA Journal 74 (3): 18-19.

21. Parks, J. T. 1993. FASB 115: It's back to the future for market value accounting. Journal of Accountancy 176 (3): 49-56.

22. Philips, G. E., 1963. The accretion concept of income. The Accounting Review 38 (1): 14.

23. Ratcliffe, T. A. 2007. The finer points of fair value. Journal of Accountancy 204 (6): 58-61. 


\section{NOTES}

